\title{
Review: Head and neck squamous cell carcinoma in sub-Saharan Africa
}

\section{CE Faggons ${ }^{1}, \mathrm{C}_{\text {Mabedi }}{ }^{2}, \mathrm{CG}$ Shores $^{1}, \mathrm{~S} \mathrm{Gopal}^{3}$}

1. Department of Otolaryngology/Head and Neck Surgery, University of North Carolina, Chapel Hill, North Carolina, USA

2. Department of Surgery, Kamuzu Central Hospital, Lilongwe, Malawi

3. UNC Project-Malawi, Lilongwe, Malawi

Correspondence to: Carol G. Shores

E-mail: carol_shores@med.unc.edu

\section{Abstract}

\section{Aim}

Review the literature from 1990 to 2013 to determine known anatomic sites, risk factors, treatments, and outcomes of head and neck squamous cell carcinoma (HNSCC) in sub-Saharan Africa.

\section{Methods}

Using a systematic search strategy, literature pertaining to HNSCC in sub-Saharan Africa was reviewed and patient demographics, anatomic sites, histology, stage, treatment, and outcomes were abstracted. The contributions of human immunodeficiency virus (HIV), human papillomavirus (HPV) and behavioural risk factors to HNSCC in the region were assessed.

\section{Results}

Of the 342 papers identified, 46 were utilized for review, including 8611 patients. In sub-Saharan Africa, the oropharyngeal/oral cavity was found to be the most common site, with 7750 cases $(90 \%$ of all cases). Few papers distinguished oropharyngeal from oral cavity, making identification of possible HPV-associated oropharyngeal squamous cell carcinoma (SCC) difficult. SCC of the nasopharynx, nasal cavity, or paranasal sinuses was identified in 410 patients (4.8\% of all cases). Laryngeal SCC was found in 385 patients ( $4.5 \%$ of all cases), and only 66 patients $(0.8 \%$ of all cases) with hypopharyngeal SCC were identified. In 862 patients with data available, $43 \%$ used tobacco and $42 \%$ used alcohol, and reported use varied widely and was more common in laryngeal SCC than that of the oropharyngeal/oral cavity. Toombak and kola nut use was reported to be higher in patients with HNSCC. Several papers reported HIV-positive patients with HNSCC, but it was not possible to determine HNSCC prevalence in HIV-positive compared to negative patients. Reports of treatment and outcomes were rare.

\section{Conclusions}

The oropharyngeal/oral cavity was by far the most commonly reported site of HNSCC reported in sub-Saharan Africa. The roles of risk factors in HNSCC incidence in sub-Saharan Africa were difficult to delineate from the available studies, but a majority of patients did not use tobacco and alcohol.

\section{Introduction}

Sub-Saharan Africa is experiencing a rapidly increasing burden of cancer-related morbidity and mortality. While annual deaths in the region resulting from human immunodeficiency virus (HIV), ${ }^{1}$ tuberculosis, ${ }^{2}$ and malaria ${ }^{3}$ are steadily declining, cancer deaths are projected to increase by $85 \%$ between 2008 and $2030 .{ }^{3}$ Moreover, these projections assume static age-specific incidence rates and are based solely on projected population growth and aging. Population-based cancer registries, however, demonstrate increasing cancer incidence, likely resulting from HIV and westernization of lifestyles. ${ }^{5,6,7}$ This suggests future cancer burden in the region may be significantly underestimated.

Earlier cancer detection via screening, insights into tumour biology and pathogenesis, as well as improved treatments and supportive care, have contributed to increasing cancer survivorship in high-income countries. However, cancer patients in sub-Saharan Africa have largely not benefited from these advances and outcomes remain poor because of severely limited resources for diagnosis and treatment, as well as possible differences in the aetiology and pathogenesis of cancer in this region. ${ }^{8}$

The sites of lip, oral cavity, nasopharynx, other pharynx, and larynx, collectively, comprised the sixth most common cancer in sub-Saharan Africa, with 18,099 reported cases in 2008. ' Upper aerodigestive tract cancers are staged according to the American Joint Commission on Cancer (AJCC) staging manual, by site and sub-site, based on the complex anatomy and physiology of the head and neck region. The aerodigestive anatomic sites delineated by AJCC are sinonasal, nasopharynx, oropharynx, oral cavity, hypopharynx, and larynx. Across all head and neck sites, the most common histology is squamous cell carcinoma (SCC).$^{10}$ Head and neck anatomy, as it pertains to staging cancers, requires specific training. There are only a limited number of head and neck surgeons in sub-Saharan Africa, and this review highlights the need for better anatomic understanding and staging.

For head and neck squamous cell carcinoma (HNSCC) patients, tobacco and alcohol use have historically been the most common risk factors. ${ }^{11}$ Although tobacco use remains uncommon in most of sub-Saharan Africa, tobacco companies are aggressively marketing cigarettes throughout the region, targeting youth in particular. ${ }^{12}$ Over the past several decades, tobacco use has increased by nearly $50 \%$ in low-and-middle-income countries (LMIC), generally, while simultaneously declining in high-income countries. ${ }^{13}$

While tobacco use has decreased in high-income countries, HNSCC burden has not significantly declined, partly explained by the emergence of human papillomavirus (HPV) as an aetiologic agent of oropharynx (OP) squamous cell carcinoma. ${ }^{14}$ In sub-Saharan Africa, infectious agents play a directly causative role in one-third of cancers, ${ }^{15}$ and HPV is the aetiologic agent of cervical cancer, the most common cancer in the region. ${ }^{6}$ However, the contribution of HPV to HNSCC in sub-Saharan Africa is not well described, particularly in settings where HIV is highly prevalent, and where HIV-infected individuals may have increased acquisition and persistence of oncogenic HPV strains at multiple anatomic sites. ${ }^{16,17}$

This is a comprehensive review of the literature pertaining to HNSCC in sub-Saharan Africa. We systematically reviewed the regional literature with respect to HNSCC, including summarizing all available data regarding patient demographics, behavioural risk factors, HIV, HPV, anatomic site, histology, stage, treatment, and outcomes. Limitations of the existing literature are highlighted, and areas for future research are proposed.

\section{Methods \\ Search strategy}

PubMed was searched for all English- or French-language papers identified using the MeSH terms "head and neck cancer", "squamous cell carcinoma", and "Africa", and limiting results to studies of human subjects. Additional papers were identified from a bibliographic search of the studies identified. Since the HIV epidemic has had major 
effects on the pattern of malignancies in the region, 1990 was chosen as the starting year for this review. Papers from North Africa were excluded, as were series reporting on fewer than five patients. For duplicative papers reporting on the same groups of patients, we included the publication describing the largest series of HNSCC patients specifically. Many studies reported on several pathologies of oral, nasal, or laryngeal neoplasms, from which data regarding HNSCC were extracted. Given that sinonasal undifferentiated carcinoma (SNUC) and nasopharyngeal carcinoma (NPC) include SCC histologies, these subtypes were included.

\section{Data analysis}

A standardized abstraction tool was developed to extract data from papers identified and to characterize studies based on inclusion and exclusion criteria. Data were abstracted from each paper with respect to primary tumour site or subsite, disease stage, patient sex, behavioural risk factors, patient HIV status, patient HPV status, treatment, complications, and outcomes. We described male-to-female ratios, substance use, HIV prevalence, HPV frequency, and tumour stage by summing the numbers of patients across all studies, stratifying by anatomic site. Data were omitted if HNSCC patients could not be extrapolated from aggregate tumour data.

\section{Anatomic classification}

Anatomic sites were not uniformly reported or defined in the studies reviewed. For our analysis, carcinomas were grouped as oral cavity (OC) and oropharynx (OP), nasal cavity (NC), nasopharynx (NP), paranasal sinuses, larynx, and hypopharynx (HP). The AJCC cancer staging manual was used to delineate these sites, as defined below. ${ }^{18}$ For papers including multiple anatomic sites, we analyzed carcinomas separately by anatomic site.

OC is defined as mucosal lip, buccal mucosa, alveolar ridge (gums or gingiva), retromolar trigone, hard palate, floor of mouth, and anterior two-thirds of the tongue. OP includes the inferior surface of the soft palate, tonsillar beds, tongue base, and lateral and posterior pharyngeal walls, from the level of the soft palate to the tip of the epiglottis. The dividing line between OC and OP is the junction of the hard and soft palate and the lingual circumvallate papillae. It was frequently not possible to distinguish OC from OP based on available data, therefore these two anatomic sites were analyzed in aggregate. NC is anatomically defined as extending from the nares to the choanae, including the turbinates. NP was defined as extending posteriorly from the choanae, including the lateral and posterior pharyngeal walls, down to the free edge of the soft palate. The paranasal sinuses include the maxillary, ethmoid, frontal, and sphenoid sinuses. The larynx subsites are the supraglottis, glottis, and subglottis. The supraglottis subsites are epiglottis, aryepiglottic folds, arytenoids and false vocal cords. The glottis includes the true vocal cords, and anterior and posterior commissures. A transglottic cancer extends through all three divisions of the larynx. HP is defined as extending inferiorly from the level of the epiglottis to the oesophageal introitus and includes three subsites: the postcricoid region, the right and left pyriform sinuses, and the posterior pharyngeal wall. ${ }^{18}$

\section{Results}

The initial PubMed search returned 330 papers, with an additional 12 papers identified using references of papers from the initial search. Of these 342 total papers, 60 included HNSCC in Africa and were published after 1990. Fourteen articles were excluded, leaving 46 studies in this review. Two excluded studies described regions other than sub-Saharan Africa. ${ }^{19,20}$ Other excluded studies were a series of patients with specifically late presentations of benign and malignant orofacial tumours, ${ }^{21}$ virological studies of pathology specimens without accompanying clinical data, ${ }^{22-24}$ and studies exclusively examining SCC metastases to salivary glands. ${ }^{25,26}$ We attempted to extrapolate HNSCC data from papers reporting SCC at multiple sites, but several papers were excluded because they only reported aggregate data, such that we could not distinguish HNSCC from the larger SCC group. Five papers that duplicated patients from other studies were excluded. ${ }^{27-31}$ Overall, 8611 patients were included in the review.

\section{Demographics, anatomic sites, and histology}

Twenty-nine papers were identified that included SCC of the OC/OP, with a total of 7750 patients $(90 \%$ of all cases identified, Table 1). The mean or median age of patients ranged from 37 years in Kenya ${ }^{39}$ to 58 years in Ghana, ${ }^{47}$ but there were insufficient patient-level data to report an aggregate mean or median age across all studies. The mean age of 37 was reported from a study of exclusively HIVinfected HNSCC patients in Kenya. ${ }^{39}$ The youngest mean age in a generalized OC/OP SCC population was 46 years from Congo. ${ }^{32}$ Male-to-female ratios ranged from $0.5: 1$ in Congo $^{32}$ to $4: 1$ in South Africa. ${ }^{44}$ Overall, there were 2.3 males per female with OC/OP SCC across all studies. The most common OC/OP subsites were the mandibular or maxillary alveolar ridge in 1007 cases (13\%), followed by the tongue in $773(10 \%)$. In $57 \%$ of cases the site was not specified. OP sites were specified in only 171 cases $(2 \%)$. The degree of differentiation was described in 835 cases (11\%). Well-differentiated, moderately differentiated, and poorly differentiated carcinomas comprised $42 \%, 37 \%$, and $25 \%$, respectively.

Ten studies, including 410 patients, reported data from patients with cancer of the nasopharynx (NP), nasal cavity (NC), or paranasal sinuses (4.8\% of all cases, Table 2$)$. Few of these studies reported age and gender, but mean or median ages ranged from 4962 to 51 years, ${ }^{63}$ and male-tofemale ratios ranged from 1.7:163 to 2.3:1.61 Among SCCs of the NC, NP, and paranasal sinuses, the maxillary sinus was the most common subsite, comprising $53 \%$ of all tumours. Among NC, NP, and paranasal sinus SCCs, 71\% were welldifferentiated. Of the $73 \mathrm{NP}$ carcinomas that were described with a WHO histologic classification, $26(46 \%)$ were class I (keratinizing, differentiated SCC), while 47 (64\%) were class II or III (undifferentiated carcinomas).

Ten studies discussed laryngeal carcinoma, including 385 patients $(4.5 \%$ of all cases, Table 3$)$. Mean or median ages ranged from 49 years in Cameroon ${ }^{68}$ to 70 years in Nigeria. ${ }^{69}$ Male-to-female ratios ranged from 6:1 in South Africa ${ }^{45}$ and Nigeria $^{70}$ to $28: 1$ in Zimbabwe, ${ }^{67}$ and the average ratio was 13:1. Lesion subsite was available for 240 patients and, of these, $62 \%$ were glottic. Two studies of laryngeal SCC noted the degree of histologic differentiation, with the majority being well-differentiated tumours $(63 \%) .{ }^{61,72}$

Two studies from Senegal discussed HP SCC, including a study of 66 patients ( $0.8 \%$ of all cases), aged 10 to 86 years, with a mean age of $33,{ }^{74}$ and a study of 15 children, aged 10 to 18 years, with a mean age of $15 .^{75}$ The aggregate maleto-female ratio was $0.9: 1$. Lesion subsite was recorded for http://dx.doi.org/10.4314/mmj.v27i3.2 
Table 1: Included studies of head and neck squamous cell carcinoma of the oral cavity and oropharynx in sub-Saharan Africa since 1990

LOCATION YEAR AUTHOR N SITES

\begin{tabular}{|c|c|c|c|c|c|c|c|c|c|c|c|}
\hline & & & & Lip & $\begin{array}{l}\text { Oral } \\
\text { mucosa }\end{array}$ & $\begin{array}{l}\text { Alveolar } \\
\text { ridge }\end{array}$ & $\begin{array}{l}\text { Floor of } \\
\text { mouth }\end{array}$ & Palate & Tongue & OP & $\begin{array}{l}\text { Not } \\
\text { specified }\end{array}$ \\
\hline \multicolumn{12}{|l|}{ Central } \\
\hline DRC & 1999 & Kayembe ${ }^{32}$ & 83 & $14(17 \%)$ & $11(13 \%)$ & $7(8 \%)$ & $6(7 \%)$ & $17(20 \%)$ & $20(24 \%)$ & - & $8(10 \%)$ \\
\hline Sudan & 2010 & Ibrahim $^{33}$ & 192 & - & - & - & - & - & - & - & $192(100 \%)$ \\
\hline Sudan & 1995 & Idris $^{34}$ & 650 & - & - & - & - & - & - & - & $650(100 \%)$ \\
\hline Sudan & 2010 & Jalouli ${ }^{35}$ & 217 & $10(5 \%)$ & $73(34 \%)$ & $50(23 \%)$ & $31(14 \%)$ & $6(3 \%)$ & $47(22 \%)$ & - & - \\
\hline Sudan & 2012 & Jalouli ${ }^{36}$ & 20 & - & - & - & - & - & $7(35 \%)$ & - & $13(65 \%)$ \\
\hline \multicolumn{12}{|l|}{ Eastern } \\
\hline Ethiopia & 1994 & Neway $^{37}$ & 16 & - & - & - & - & - & - & - & $16(100 \%)$ \\
\hline Kenya & 2008 & Butt $^{38}$ & 9 & - & - & $7(78 \%)$ & - & $2(22 \%)$ & - & - & - \\
\hline Kenya & 2012 & Butt $^{39}$ & 16 & $2(13 \%)$ & $2(13 \%)$ & $2(13 \%)$ & $3(19 \%)$ & - & $5(31 \%)$ & $2(13 \%)$ & - \\
\hline Kenya & 2007 & $\operatorname{Dimba}^{40}$ & 187 & $10(5 \%)$ & $32(17 \%)$ & $31(17 \%)$ & $32(17 \%)$ & $25(13 \%)$ & $35(19 \%)$ & $1(1 \%)$ & $21(11 \%)$ \\
\hline Kenya & 1992 & Maroo $^{41}$ & 17 & - & $7(41 \%)$ & $3(18 \%)$ & $4(24 \%)$ & $2(12 \%)$ & $1(6 \%)$ & - & - \\
\hline Kenya & 1995 & Onyango $^{42}$ & 580 & $53(9 \%)$ & $23(4 \%)$ & $107(18 \%)$ & $31(5 \%)$ & $93(16 \%)$ & 149 (26\%) & - & $124(21 \%)$ \\
\hline Kenya & 2004 & Onyango ${ }^{43}$ & 821 & $86(10 \%)$ & $86(10 \%)$ & $242(29 \%)$ & $63(8 \%)$ & - & $220(27 \%)$ & $124(15 \%)$ & - \\
\hline \multicolumn{12}{|l|}{ Southern } \\
\hline RSA & 1996 & Hille $^{44}$ & 3070 & - & - & - & - & - & - & - & 3070 (100\%) \\
\hline RSA & 2002 & $\begin{array}{l}\text { Pacella- } \\
\text { Norman }^{45}\end{array}$ & 124 & - & - & - & - & - & - & - & $124(100 \%)$ \\
\hline Zimbabwe & 2006 & Chidzonga $^{46}$ & 313 & $14(4 \%)$ & $33(11 \%)$ & $99(32 \%)$ & $58(19 \%)$ & $28(9 \%)$ & $64(20 \%)$ & $17(5 \%)$ & - \\
\hline \multicolumn{12}{|l|}{ Western } \\
\hline Ghana & 2009 & Parkins $^{47}$ & 69 & $5(7 \%)$ & $5(7 \%)$ & 37 (54\%) & $4(6 \%)$ & - & $12(17 \%)$ & $2(3 \%)$ & $4(6 \%)$ \\
\hline Nigeria & 1991 & Abiose $^{48}$ & 75 & $10(13 \%)$ & $3(4 \%)$ & $20(27 \%)$ & $4(5 \%)$ & $25(33 \%)$ & $11(15 \%)$ & - & $2(3 \%)$ \\
\hline Nigeria & 2002 & Adewole ${ }^{49}$ & 58 & $4(7 \%)$ & $10(17 \%)$ & $11(19 \%)$ & $10(17 \%)$ & - & $10(17 \%)$ & - & $13(22 \%)$ \\
\hline Nigeria & 2011 & Adeyemi $^{50}$ & 181 & $9(5 \%)$ & $16(9 \%)$ & $84(46 \%)$ & $8(4 \%)$ & $36(20 \%)$ & $28(15 \%)$ & - & - \\
\hline Nigeria & 2007 & Ajayi $^{51}$ & 112 & $2(2 \%)$ & $5(4 \%)$ & $63(56 \%)$ & $8(7 \%)$ & $13(12 \%)$ & - & $10(9 \%)$ & $11(10 \%)$ \\
\hline Nigeria & 2004 & Amusa $^{52}$ & 24 & $1(4 \%)$ & - & $10(42 \%)$ & - & $4(17 \%)$ & $3(13 \%)$ & $6(25 \%)$ & - \\
\hline Nigeria & 1999 & Arotiba $^{53}$ & 246 & $16(7 \%)$ & $13(5 \%)$ & $82(33 \%)$ & $16(7 \%)$ & $57(23 \%)$ & $48(20 \%)$ & - & $14(6 \%)$ \\
\hline Nigeria & 2006 & Arotiba $^{54}$ & 91 & $4(4 \%)$ & $10(11 \%)$ & $14(15 \%)$ & $9(10 \%)$ & $23(25 \%)$ & $23(25 \%)$ & $7(8 \%)$ & $1(1 \%)$ \\
\hline Nigeria & 2008 & Effiom $^{55}$ & 233 & $18(8 \%)$ & 31 (13\%) & $128(55 \%)$ & $15(6 \%)$ & - & $41(18 \%)$ & - & - \\
\hline Nigeria & 2011 & Lawal $^{56}$ & 32 & - & - & - & - & - & - & - & 32 (100\%) \\
\hline Nigeria & 1997 & Lawoyin $^{57}$ & 90 & $15(17 \%)$ & $6(7 \%)$ & $7(8 \%)$ & $2(2 \%)$ & $36(40 \%)$ & $22(24 \%)$ & $2(2 \%)$ & - \\
\hline Nigeria & 2007 & $O \mathrm{ji}^{58}$ & 81 & $12(15 \%)$ & - & - & $17(21 \%)$ & - & $24(30 \%)$ & - & $28(35 \%)$ \\
\hline Nigeria & 2005 & Otoh $^{59}$ & 28 & $5(18 \%)$ & $2(7 \%)$ & $3(11 \%)$ & $4(14 \%)$ & $8(29 \%)$ & $3(11 \%)$ & - & $3(11 \%)$ \\
\hline Nigeria & 2000 & Rafindadi $^{60}$ & 115 & - & - & - & - & - & - & - & 115 (100\%) \\
\hline Total & & & 7750 & $290(4 \%)$ & $368(5 \%)$ & $\begin{array}{l}1007 \\
(13 \%)\end{array}$ & $325(4 \%)$ & $375(5 \%)$ & 773 (10\%) & $171(2 \%)$ & 4441 (57\%) \\
\hline
\end{tabular}

DRC = Democratic Republic of Congo

RSA = Republic of South Africa

$\mathrm{OP}=$ Oropharynx 
Table 2: Included studies of head and neck squamous cell carcinoma of the nasopharynx, nasal cavity, and paranasal sinuses in sub-Saharan Africa since 1990

\begin{tabular}{|c|c|c|c|c|c|c|c|}
\hline COUNTRY & YEAR & AUTHOR & $\mathbf{N}$ & SITES & & & \\
\hline & & & & Nasal cavity & Nasopharynx & Maxillary sinus & Not specified \\
\hline \multicolumn{8}{|l|}{ Eastern } \\
\hline Kenya & 1998 & Oburra $^{61}$ & 34 & - & $2(6 \%)$ & - & 32 (94\%) \\
\hline Kenya & 1995 & Onyango ${ }^{42}$ & 11 & - & - & $11(100 \%)$ & - \\
\hline \multicolumn{8}{|l|}{ Southern } \\
\hline Zimbabwe & 2006 & Chidzonga $^{46}$ & 45 & - & - & 45 (100\%) & - \\
\hline \multicolumn{8}{|l|}{ Western } \\
\hline Nigeria & 2010 & Afolabi ${ }^{62}$ & 34 & - & $34(100 \%)$ & - & - \\
\hline Nigeria & 2004 & Amusa $^{52}$ & 9 & - & $8(89 \%)$ & $1(11 \%)$ & - \\
\hline Nigeria & 1998 & Arotiba $^{63}$ & 73 & - & - & $73(100 \%)$ & - \\
\hline Nigeria & 2006 & Arotiba $^{54}$ & 70 & - & - & 70 (100\%) & - \\
\hline Nigeria & 2007 & Fansula $^{64}$ & 69 & - & - & - & $69(100 \%)$ \\
\hline Nigeria & 1999 & da Lilly-Tariah ${ }^{65}$ & 43 & - & 43 (100\%) & - & - \\
\hline Nigeria & 2003 & da Lilly-Tariah ${ }^{66}$ & 22 & - & - & - & $22(100 \%)$ \\
\hline Total & & & 410 & & 87 (21\%) & 200 (49\%) & $123(30 \%)$ \\
\hline
\end{tabular}

Table 3: Included studies of head and neck squamous cell carcinoma of the larynx in sub-Saharan Africa since 1990

\begin{tabular}{|c|c|c|c|c|c|c|c|c|}
\hline \multirow[t]{2}{*}{ COUNTRY } & \multirow[t]{2}{*}{ YEAR } & \multirow[t]{2}{*}{ AUTHOR } & \multirow[t]{2}{*}{$\mathbf{N}$} & \multicolumn{5}{|l|}{ SITES } \\
\hline & & & & Supraglottic & Glottic & Subglottic & Transglottic & Not specified \\
\hline \multicolumn{9}{|l|}{ Eastern } \\
\hline Kenya & 1998 & Oburra $^{61}$ & 22 & - & - & - & - & 22 (100\%) \\
\hline \multicolumn{9}{|l|}{ Southern } \\
\hline RSA & 2002 & $\begin{array}{l}\text { Pacella- } \\
\text { Norman }{ }^{45}\end{array}$ & 59 & - & - & - & - & 59 (100\%) \\
\hline Zimbabwe & 1993 & $\begin{array}{l}\text { Tumushime- } \\
\text { Buturo } 67\end{array}$ & 114 & $30(26 \%)$ & 71 (62\%) & $2(2 \%)$ & - & $11(10 \%)$ \\
\hline \multicolumn{9}{|l|}{ Western } \\
\hline Cameroon & 2006 & Oyono $^{68}$ & 10 & - & - & - & - & $10(100 \%)$ \\
\hline Nigeria & 2004 & Amusa ${ }^{52}$ & 6 & - & - & - & - & $6(100 \%)$ \\
\hline Nigeria & 2009 & Amusa $^{69}$ & 13 & - & - & - & - & $13(100 \%)$ \\
\hline Nigeria & 2011 & Iseh $^{70}$ & 20 & - & - & - & 20 (100\%) & - \\
\hline Nigeria & 2002 & Nwaorgu $^{71}$ & 72 & $10(14 \%)$ & 40 (56\%) & - & - & $22(31 \%)$ \\
\hline Nigeria & 2003 & Somefun $^{72}$ & 36 & $3(8 \%)$ & $21(57 \%)$ & $5(14 \%)$ & $8(22 \%)$ & - \\
\hline Togo & 1999 & Kpemissi $^{73}$ & 33 & - & $16(50 \%)$ & - & $14(44 \%)$ & $2(6 \%)$ \\
\hline Total & & & 385 & 43 (11\%) & $148(38 \%)$ & $7(2 \%)$ & $42(11 \%)$ & 145 (38\%) \\
\hline
\end{tabular}

RSA = Republic of South Africa 
all patients; $30(37 \%)$ were pyriform sinus, $18(22 \%)$ were posterior pharyngeal wall, seven $(9 \%)$ were oesophageal introitus, four $(5 \%)$ were postcricoid, and $22(27 \%)$ were too advanced to determine a primary subsite.

\section{Substance use}

Only $527(7 \%)$ of the 7750 OP/OC SCC patients had traditional behavioural risk factors reported, with $35 \%$ of them having used tobacco and $32 \%$ having used alcohol (Table 4). Data regarding tobacco and alcohol use were available for $335(87 \%)$ of the 385 patients with laryngeal SCC and demonstrated that $56 \%$ of patients used tobacco and 56\% used alcohol (Table 4). Among hypopharyngeal SCCs, one study of 15 patients (aged 10 to 18 years) noted that no patient used tobacco or alcohol, ${ }^{75}$ while another study noted that $13(20 \%)$ of 66 of patients used tobacco, with alcohol use not reported. ${ }^{74}$ Duration and amount of use was not consistently reported, and no study specified how tobacco or alcohol use was determined. As shown in Table 4, the proportion of patients who reported alcohol and tobacco use ranged widely across individual studies. A study in South Africa reported $96 \%$ and $88 \%$ of men using tobacco and alcohol, respectively, ${ }^{45}$ while a study from Nigeria reported only $14 \%$ use of each substance. ${ }^{72}$ Several studies reporting nil alcohol use among HNSCC patients were conducted in predominantly Muslim populations and noted that patients self-reporting alcohol use would not be socially acceptable.

Table 4: Tobacco and alcohol use by country and HNSCC site among included studies from sub-Saharan Africa since 1990

\begin{tabular}{|c|c|c|c|c|c|}
\hline COUNTRY & AUTHOR & SITE & $n^{*}$ & TOBACCO USE $\mathrm{n}(\%)$ & ALCOHOL USE n (\%) \\
\hline \multicolumn{6}{|l|}{ Central } \\
\hline Sudan & Ibrahim ${ }^{33}$ & OP/OC & 192 & $26(14 \%)$ & $24(13 \%)$ \\
\hline Sudan & Jalouli ${ }^{36}$ & $\mathrm{OP} / \mathrm{OC}$ & 20 & $15(75 \%)$ & $0(0 \%)$ \\
\hline \multicolumn{6}{|l|}{ Eastern } \\
\hline Kenya & Butt $^{39}$ & $\mathrm{OP} / \mathrm{OC}$ & 16 & $4(25 \%)$ & $5(31 \%)$ \\
\hline \multicolumn{6}{|l|}{ Southern } \\
\hline RSA & Pacella-Norman ${ }^{45}$ & $\mathrm{OP} / \mathrm{OC}$ & 124 & $97(78 \%)$ & $94(76 \%)$ \\
\hline RSA & Pacella-Norman ${ }^{45}$ & Larynx & 51 & $49(96 \%)$ & $45(88 \%)$ \\
\hline Zimbabwe & $\begin{array}{l}\text { Tumushime- } \\
\text { Buturo }{ }^{67}\end{array}$ & Larynx & 114 & $57(50 \%)$ & $57(50 \%)$ \\
\hline \multicolumn{6}{|l|}{ Western } \\
\hline Nigeria & Adewole $^{49}$ & $\mathrm{OP} / \mathrm{OC}$ & 50 & $30(60 \%)$ & $36(72 \%)$ \\
\hline Nigeria & Lawal $^{56}$ & $\mathrm{OP} / \mathrm{OC}$ & 32 & $8(25 \%)$ & $8(25 \%)$ \\
\hline Nigeria & $\mathrm{Oji}^{58}$ & $\mathrm{OP} / \mathrm{OC}$ & 81 & $0(0 \%)$ & $0(0 \%)$ \\
\hline Nigeria & Otoh $^{59}$ & $\mathrm{OP} / \mathrm{OC}$ & 12 & $2(17 \%)$ & $1(8 \%)$ \\
\hline Nigeria & Amusa $^{69}$ & Larynx & 13 & $5(38 \%)$ & $11(85 \%)$ \\
\hline Nigeria & $\operatorname{Iseh}^{70}$ & Larynx & 20 & $20(100 \%)$ & $0(0 \%)$ \\
\hline Nigeria & Nwaorgu $^{71}$ & Larynx & 68 & $30(44 \%)$ & $47(69 \%)$ \\
\hline Nigeria & Somefun $^{72}$ & Larynx & 36 & $5(14 \%)$ & $5(14 \%)$ \\
\hline Togo & Kpemissi $^{73}$ & Larynx & 33 & $26(79 \%)$ & $27(82 \%)$ \\
\hline Total & & & 862 & 374 (43\%) & 360 (42\%) \\
\hline
\end{tabular}

Another substance reported to be associated with HNSCC is toombak, a fermented and cured tobacco product, commonly used-by placing a portion in the buccal sulcus - in the northernmost regions of sub-Saharan Africa. One Sudanese study reported that $58 \%$ of patients with lip, buccal mucosa, and floor of mouth cancer used toombak, while only $19 \%$ of patients with tongue, palate, and maxillary sinus cancer reported the same, though rates of toombak use by anatomic site were not reported. ${ }^{36} \mathrm{~A}$ second Sudanese study showed that $67 \%$ of patients with OP/OC SCC used toombak. ${ }^{35}$ Toombak use was most common in SCC of the oral mucosa, of which $83 \%$ of patients were users. Least commonly, only $40 \%$ of tongue SCC patients reported toombak use. Oropharynx subsites were not indicated separately. Other studies did not report smokeless tobacco use separately. Another potentially associated substance is kola nut, a stimulant used both socially and ceremonially in many forested regions of sub-Saharan Africa. ${ }^{76}$ The raw product can be chewed or the nut can be processed into a beverage. A study from Nigeria observed that four of five patients with OP/OC SCC reported using kola nut. ${ }^{59}$

\section{HIV and HPV}

Two studies prospectively identified HIV-infected patients with OC/OP tumours but did not compare this group to HIV-uninfected patients. ${ }^{38,39}$ In the first study, $16 \mathrm{HIV}$ infected patients with OC/OP SCC were identified, including five with SCC of the tongue, three of the floor of the mouth, two of the gingivae, two with OP SCC, two with lip SCC, and two with buccal mucosa SCC. The mean or median age was 32 years, and $44 \%$ were male. The authors also found that $63 \%$ of cancers were high-grade, poorly differentiated malignancies, and $44 \%$ were stage IV at presentation. It was noted that $25 \%$ and $31 \%$ of patients reported tobacco and alcohol use, respectively. ${ }^{38}$ The other study identified nine HIV-infected patients with HNSCC, with a mean age of 36 , including two palatal, and seven alveolar ridge tumours. ${ }^{39}$ Treatment and outcomes were not described in either study. Other studies anecdotally reported that HIV-infected patients had worse outcomes and were often not surgical candidates. However, no study described patient characteristics or outcomes in HIV-infected and HIVuninfected HNSCC populations separately for comparison.

One study tested 155 OP/OC SCC specimens from patients in eight countries using PCR for HPV, herpes simplex virus (HSV), and Epstein-Barr virus (EBV). ${ }^{36}$ Tumour HPV positivity was highest in Sudan, the only country in sub-Saharan Africa included in the study. No mention was made of patient demographics, site, stage, HIV status, or behavioural risk factors, in relation to tumour HPV status. Additionally, OC and OP tumours were not distinguished and analyzed separately. A second study of 217 OP/OC SCC specimens in Sudan showed that $25 \%$ of specimens were positive for HPV, and that more patients reporting toombak use had HPV-positive tumours $(27 \%)$ than those who did not use toombak (21\%), although these differences were not statistically significant. ${ }^{35} \mathrm{HPV}$ positivity was reported by anatomic subsite, however no clear anatomic trends were described and oropharynx sites were not designated. One study of 15 hypopharyngeal SCCs noted that one patient had severe oral and labial papillomatosis, although HPV confirmatory testing was not performed. ${ }^{75}$

\section{Staging, treatment, and outcome}

Stage was reported for $543(6 \%)$ of 8611 patients, and late presentations were common for all anatomic sites. Overall, $3 \%$ of HNSCCs were stage I, $6 \%$ were stage II, $52 \%$ were stage III, and 39\% were stage IV. No study described using nasopharyngoscopy, computed tomography (CT), or magnetic resonance imaging (MRI) for staging, and most papers reported that these were not available.

Only one of 28 studies describing OP/OC SCC reported 
treatment for 146 patients in Nigeria. ${ }^{53}$ Twenty-one patients $(14 \%)$ declined treatment, $22(15 \%)$ underwent palliative chemotherapy or radiation, and the remainder underwent surgery, chemotherapy, radiation, or a combination with curative intent. Limited outcomes were reported as 113 patients $(77 \%)$ were lost to follow-up within two weeks of enrolment.

Seven of 11 laryngeal SCC studies discuss treatment, and all reported patients frequently presenting with airway emergencies requiring emergent tracheostomy before definitive treatment. Radiotherapy was used alone or with other treatment modalities in $70 \%$ of patients, and outcome data were limited. Patients from studies in Zimbabwe, ${ }^{67}$ Togo, ${ }^{73}$ Nigeria, ${ }^{69,70}$ and Cameroon $^{68}$ received radiation therapy. Several studies noted patients who refused treatment, though reasons were not given. With respect to treatment complications, one series reported five of 33 patients developing pharyngocutanenous fistulae. ${ }^{67}$ In another series of nine patients, two developed pharyngocutaneous fistulae, while pharyngeal stenosis, stomal stenosis, hypothyroidism, and hypocalcaemia were reported in individual cases. ${ }^{69}$ Another series reported pharyngocutaneous fistula in one of three patients who underwent surgery and radiation. ${ }^{68}$ One series of five patients who underwent postoperative radiation noted that two died from carotid artery rupture. ${ }^{70}$ Rates of mucositis, malnutrition, and infectious complications, common causes of treatment-related morbidity in resourcerich settings, were not reported in any study.

Among HP SCCs, ${ }^{74,75}$ two patients (3\%) underwent surgery followed by radiation, three patients (4\%) underwent surgery alone and 28 patients $(35 \%)$ underwent radiation alone, while $48(59 \%)$ underwent only palliative tracheostomy or gastrostomy. Within three years of follow-up, 77 patients $(95 \%)$ had died and the remaining four $(5 \%)$ were lost to follow-up.

\section{Discussion}

To our knowledge, this is the first systematic review of the existing literature of HNSCC in sub-Saharan Africa.

Obstacles to collecting accurate data with respect to age in sub-Saharan Africa are well described. ${ }^{77}$ In the studies reviewed, however, age at presentation was approximately 20 years younger for HNSCC patients than in the US. ${ }^{78,79}$ Younger age at diagnosis compared with high-income countries has been consistently noted for many cancers in sub-Saharan Africa, and this may reflect biologic differences with respect to cancer pathogenesis and susceptibility, or differences in population age structure, or a combination of both factors. ${ }^{8}$

Established risk factors for HNSCC in high-income countries include smoking, alcohol use, and older age. Overall, of the sub-Saharan HNSCC patients for whom environmental exposures were reported, more than half were non-smokers and denied alcohol use, implying a different set of risk factors compared to high-income countries. However, the data are difficult to analyze. Several studies noted the overall prevalence of tobacco and alcohol use among HNSCC cases, but very few reported the actual number of patients using these substances or the prevalence of tobacco and alcohol use in the general population. Some studies noted that social norms might prevent patients from openly reporting substance use, an inherent limitation of self-reported data. ${ }^{80}$
Clearer descriptions of anatomy and stage would lead to a better understanding of HNSCC in sub-Saharan Africa. In high-income countries, the incidence of HNSCC attributable to tobacco and alcohol is decreasing, ${ }^{81}$ while incidence of HPV-associated oropharyngeal SCC is increasing. ${ }^{82}$ In the reviewed studies, only $2 \%$ of OC/OP cases specified $\mathrm{OP}$ as the site, although many papers described tongue or palate tumours that spanned both OC and OP. The lack of advanced imaging and nasopharyngoscopy severely limits the ability of providers to make distinctions regarding anatomic sites and disease stage. The scarcity of staging information may also be due to a lack of familiarity among providers with the complex anatomy and staging of HNSCC. These distinctions have implications in prognosis and treatment. In high-income countries, HPV-positive OP SCC patients have better outcomes than HPV-negative OP patients (and those with HNSCC in other sites) ${ }^{83,84}$ and are increasingly treated with deintensification strategies, which include surgery as a single modality. ${ }^{85}$ Surgery is available in many sub-Saharan African countries where radiotherapy is not and, therefore, distinguishing OP from OC SCC might influence treatment recommendations.

One study from Sudan reported that two-thirds of OP/ OC SCCs were positive for HPV, ${ }^{36}$ while a second study from Sudan reported one-quarter of OP/OC SCC to be positive. $^{35}$ Another study, which did not meet criteria for inclusion because of missing clinical data, found only two of 146 OP/OC SCCs from black South Africans to be positive for HPV (subtypes 6, 11, 16, 18). ${ }^{23}$ Another study of three female patients with laryngeal cancer in Congo noted one tumour to be histologically consistent with HPV, although no confirmatory testing was done. ${ }^{86,87}$ These conflicting results underscore the need for further research into the role of $\mathrm{HPV}$ in HNSCC in sub-Saharan Africa. HPV vaccination is a high priority for many ministries of health throughout the region, to reduce the immense burden of cervical cancer. ${ }^{88,89}$ If $\mathrm{HPV}$ is a significant contributor to HNSCC, introducing $\mathrm{HPV}$ vaccination may reduce HNSCC burden, in addition to reducing cervical and anal cancer. Long-term monitoring of HNSCC incidence in countries where HPV vaccination has been introduced will be highly informative.

In the US, HIV infection is associated with a two- to threefold increased risk of HNSCC, ${ }^{90}$ although whether this results from increasing mucosal HPV rates and greater susceptibility to HPV oncogenesis, increased tobacco and alcohol use, or both, is uncertain. ${ }^{91}$ Limited data suggest that HIV-infected HNSCC patients in sub-Saharan Africa may be younger, with infrequent tobacco and alcohol use, more aggressive cancers, and worse clinical outcomes. ${ }^{38,39}$ The effect of antiretroviral therapy (ART) scale-up on cancer incidence overall, and HNSCC incidence specifically, remains uncertain. Further cancer research in settings with high HIV prevalence can clarify these relationships and inform both ART and cancer treatment programmes.

HNSCC is frequently treated with surgery. General surgeons can perform diagnostic biopsies and tracheostomies when indicated, but there is an extreme scarcity of head and neck surgeons to perform curative surgeries for HNSCC in sub-Saharan Africa. A survey of 18 sub-Saharan African countries in 2008 identified one ENT surgeon per million population. If South Africa is excluded, there were 0.6 ENT surgeons per million population, ${ }^{92}$ compared with 28 per million population in the US. ${ }^{93,94}$ Pathology services are also 
lacking, with less than one pathologist per million population in Nigeria, ${ }^{95}$ Tanzania, ${ }^{96}$ and Uganda, ${ }^{97}$ versus 51 per million population in the US. ${ }^{94,98}$ Similarly, there are fewer than one medical oncologist per million population in Ethiopia ${ }^{99,100}$ and Malawi compared with 43 per million population in the US. ${ }^{94,101}$

Radiation is also a mainstay of HNSCC treatment and can be used alone, in combination with chemotherapy, or following surgery. However, radiotherapy can lead to complications, particularly in settings where treatment may be administered using older units, without modern techniques to minimize toxicity. ${ }^{102}$ No studies reported rates of mucositis, infection, or malnutrition in patients receiving radiotherapy, although these are frequently observed complications in resource-rich settings. Even when safely administered, radiotherapy units are severely limited throughout sub-Saharan Africa, which has only 88 radiotherapy facilities overall, of which 53 are in South Africa or Nigeria. Twenty-seven countries within the region have no radiotherapy at all, and of the countries that do administer radiotherapy, most have only a single operational unit. ${ }^{103}$

HNSCC is a complex disease that is incompletely described in sub-Saharan Africa. As with many other disease entities, improvement in medical infrastructure will improve diagnosis, treatment, and outcomes.

\section{References}

1. UNAIDS world AIDS day report 2012 fact sheet: Sub-Saharan Africa [Internet]. Geneva: Joint United Nations Program on HIV/ AIDS (UNAIDS); 2012; cited March 6,2013]. Available from: http://www.unaids.org/en/media/unaids/contentassets/documents/ epidemiology/2012/gr2012/2012_FS_regional_ssa_en.pdf.

2. Global tuberculosis report 2012 [Internet]. Geneva: World Health Organization; 2012; cited March 6, 2013]. Available from: http://www. who.int/tb/publications/global_report/en/index.html.

3. World malaria report 2012 [Internet]. Geneva: World Health Organization; 2012; cited March, 6 2013]. Available from: http://www. who.int/malaria/publications/world_malaria_report_2012/en/index. html.

4. Bray F, Ren JS, Masuyer E, Ferlay J. Global estimates of cancer prevalence for 27 sites in the adult population in 2008. Int J Cancer. 2013 Mar 1;132(5):1133-45.

5. Parkin DM, Nambooze S, Wabwire-Mangen F, Wabinga HR. Changing cancer incidence in Kampala, Uganda, 1991-2006. Int J Cancer. 2010 Mar 1;126(5):1187-95.

6. Chokunonga E, Borok MZ, Chirenje ZM, Nyakabau AM, Parkin DM. Trends in the incidence of cancer in the black population of Harare, Zimbabwe 1991-2010. Int J Cancer. 2013 Jan 30.

7. Msyamboza KP, Dzamalala C, Mdokwe C, Kamiza S, Lemerani M, Dzowela T, et al. Burden of cancer in Malawi; common types, incidence and trends: National population-based cancer registry. BMC Res Notes. 2012 Mar 16;5:149,0500-5-149.

8. Parkin DM, Sitas F, Chirenje M, Stein L, Abratt R, Wabinga H. Part I: Cancer in indigenous Africans--burden, distribution, and trends. Lancet Oncol. 2008 Jul;9(7):683-92.

9. Ferlay J, Shin HR, Bray F, Forman D, Mathers C and Parkin DM. GLOBOCAN 2008 v2.0, Cancer Incidence and Mortality Worldwide: IARC CancerBase No. 10 [Internet]. Lyon, France: International Agency for Research on Cancer; 2010. Available from: http://globocan. iarc.fr, accessed on March 6,2013

10. Barnes L, Eveson JW, Reichart P, Sidransky D, editors. World Health Organization classification of tumours. Pathology and Genetics: Head and neck tumours. Lyon: IARC Press; 2005.
11. World Health Organization International Agency for Research on Cancer. IARC monographs on the evaluation of carcinogenic risk to humans: Volume 83 tobacco smoke and involuntary smoking. Lyon, France: World Health Organization; 2004. Report No.: 83.

12. WHO report on the global tobacco epidemic, 2009: Implementing smoke-free environments. Geneva: World Health Organization; 2009; cited March 6, 2013]. Available from: http:/www.who.int/tobacco/ mpower/2009/en/index.html.

13. Guindon, G. Emmanuel; \& Boisclair, David. (2003). Past, Current and Future Trends in Tobacco Use. UC San Francisco: Center for Tobacco Control Research and Education. Retrieved from: http://www. escholarship.org/uc/item/4q57d5vp, accessed on February 25, 2013

14. Goon PK, Stanley MA, Ebmeyer J, Steinstrasser L, Upile T, Jerjes W, et al. HPV \& head and neck cancer: A descriptive update. Head Neck Oncol. 2009 Oct 14;1:36,3284-1-36.

15. de Martel C, Ferlay J, Franceschi S, Vignat J, Bray F, Forman D, et al. Global burden of cancers attributable to infections in 2008: A review and synthetic analysis. Lancet Oncol. 2012 Jun;13(6):607-15.

16. Palefsky JM, Minkoff H, Kalish LA, Levine A, Sacks HS, Garcia $\mathrm{P}$, et al. Cervicovaginal human papillomavirus infection in human immunodeficiency virus-1 (HIV)-positive and high-risk HIV-negative women. J Natl Cancer Inst. 1999 Feb 3;91(3):226-36.

17. Palefsky JM, Holly EA, Ralston ML, Jay N. Prevalence and risk factors for human papillomavirus infection of the anal canal in human immunodeficiency virus (HIV)-positive and HIV-negative homosexual men. J Infect Dis. 1998 Feb;177(2):361-7.

18. American Joint Committee on Cancer. AJCC cancer staging manual. 7th ed. Edge SB, Byrd DR, Compton CC, Fritz AG, Greene FL, Trotti IA, editors. New York Dordrecht Heidelberg London: Springer; 2010.

19. Saleh EM, Abdulliwahab AA, Kammal MM. Age and sex incidence of hypopharyngeal tumors in upper Egypt: Assuit University experience. J Laryngo Otol. 1995;109:737-740.

20. Kamel AH, el-Barawy, Hashish MH, el-Sheikh SM. Epstein-Barr virus in head and neck squamous cell carcinoma. East Mediterr Health J. 2003 May;9(3):364-71.

21. Oji C. Late presentation of orofacial tumours. J Craniomaxillofac Surg. 1999 Apr;27(2):94-9.

22. Van Rensburg EJ, van Heerden WF, Venter EH, Raubenheimer EJ. Detection of human papillomavirus DNA with in situ hybridisation in oral squamous carcinoma in a rural black population. S Afr Med J. 1995 Sep;85(9):894-6.

23. Van Rensburg EJ, Engelbrecht S, Van Heerden WF, Raubennheimer EJ, Schoub BD. Human papillomavirus DNA in oral squamous cell carcinomas from an African population sample. Anticancer Res. 1996 Mar-Apr;16(2):969-73.

24. Boy S, Van Rensburg EJ, Engelbrecht S, Dreyer L, van Heerden $\mathrm{M}$, van Heerden W. HPV detection in primary intra-oral squamous cell carcinomas--commensal, aetiological agent or contamination? J Oral Pathol Med. 2006 Feb;35(2):86-90.

25. Naidu TK, Naidoo SK, Ramdial PK. Oral cavity squamous cell carcinoma metastasis to the submandibular gland. J Laryngol Otol. 2012 Mar;126(3):279-84

26. Konan KE, N'Guessan ND, Anzouan KE, Assouan C, Edouma BG, Assa A. Diagnostic and therapeutic aspects of parotid tumors in the maxillofacial surgery department of the university hospital center in Treichville, Abidjan. Odontostomatol Trop. 2010 Dec;33(132):11-7.

27. Lawoyin JO, Lawoyin DO, Fasola AO, Kolude B. Intra-oral squamous cell carcinoma in Nigerians under 40 years of age: A clinicopathological review of eight cases. Afr J Med Med Sci. 2005 Mar;34(1):99-102.

28. Chidzonga MM. Oral malignant neoplasia: A survey of 428 cases in two Zimbabwean hospitals. Oral Oncol. 2006 Feb;42(2):177-83.

http://dx.doi.org/10.4314/mmj.v27i3.2 
29. Chidzonga MM. Lip cancer in Zimbabwe. report of 14 cases. Int J Oral Maxillofac Surg. 2005 Mar;34(2):149-51.

30. Adeyemi BF, Olusanya AA, Lawoyin JO. Oral squamous cell carcinoma, socioeconomic status and history of exposure to alcohol and tobacco. J Natl Med Assoc. 2011 Jun;103(6):498-502.

31. Amusa YB, Badmus A, Olabanji JK, Oyebamiji EO. Laryngeal carcinoma: Experience in Ile-Ife, Nigeria. Niger J Clin Pract. 2011 JanMar;14(1):74-8.

32. Kayembe MK, Kalengayi MM. Histological and epidemiological profile of oral cancer in Congo (Zaire). Odontostomatol Trop. 1999 Dec;22(88):29-32.

33. Ibrahim S, Osman T, Satti A, Suleiman A, Yang Y. Title: Pattern of malignant tumors registered at a referral oral and maxillofacial hospital in Sudan during 2006 and 2007. JCRT. 2010 Oct-Dec;5(4):473.

34. Idris AM, Ahmed HM, Mukhtar BI, Gadir AF, el-Beshir EI. Descriptive epidemiology of oral neoplasms in Sudan 1970-1985 and the role of toombak. Int J Cancer. 1995 Apr 10;61(2):155-8.

35. Jalouli J, Ibrahim SO, Sapkota D, Jalouli MM, Vasstrand EN, Hirsch $\mathrm{JM}$, et al. Presence of human papilloma virus, herpes simplex virus and Epstein-Barr virus DNA in oral biopsies from Sudanese patients with regard to toombak use. J Oral Pathol Med. 2010 Sep;39(8):599-604.

36. Jalouli J, Jalouli MM, Sapkota D, Ibrahim SO, Larsson PA, Sand L. Human papilloma virus, herpes simplex virus and Epstein Barr virus in oral squamous cell carcinoma from eight different countries. Anticancer Res. 2012 Feb;32(2):571-80.

37. Neway M, Eshete S, Minasse M. Oro-facial tumours in Ethiopian patients. clinical analysis of 108 cases and a review of the literature. J Craniomaxillofac Surg. 1994 Apr;22(2):76-80.

38. Butt FM, Chindia ML, Rana F, Machigo FG. Pattern of head and neck malignant neoplasms in HIV-infected patients in Kenya. Int J Oral Maxillofac Surg. 2008 Oct;37(10):907-11.

39. Butt FM, Chindia ML, Rana F. Oral squamous cell carcinoma in human immunodeficiency virus positive patients: Clinicopathological audit. J Laryngol Otol. 2012 Mar;126(3):276-8.

40. Dimba EA, Gichana J, Limo AK, Wakoli KA, Chindia ML, Awange DO. An audit of oral diseases at a Nairobi Centre, 2000-2004. Int Dent J. 2007 Dec;57(6):439-44.

41. Maroo SV. Clinico-radiological presentation of squamous cell carcinoma of the mouth at Kenyatta national hospital. East Afr Med J. 1992 Apr;69(4):200-4.

42. Onyango JF, Awange DO, Wakiaga JM. Oral tumours and tumourlike conditions in Kenya: II. age, sex and site distribution. East Afr Med J. 1995 Sep;72(9):568-76.

43. Onyango JF, Omondi BI, Njiru A, Awange OO. Oral cancer at Kenyatta national hospital, Nairobi. East Afr Med J. 2004 Jun;81(6):31821.

44. Hille JJ, Shear M, Sitas F. Age standardized incidence rates of oral cancer in South Africa, 1988-1991. J Dent Assoc S Afr. 1996 Dec;51(12):771-6.

45. Pacella-Norman R, Urban MI, Sitas F, Carrara H, Sur R, Hale M, et al. Risk factors for oesophageal, lung, oral and laryngeal cancers in black south Africans. Br J Cancer. 2002 Jun 5;86(11):1751-6.

46. Chidzonga MM, Mahomva L. Squamous cell carcinoma of the oral cavity, maxillary antrum and lip in a Zimbabwean population: A descriptive epidemiological study. Oral Oncol. 2006 Feb;42(2):184-9.

47. Parkins GE, Armah GA, Tettey Y. Orofacial tumours and tumourlike lesions in Ghana: A 6-year prospective study. Br J Oral Maxillofac Surg. 2009 Oct;47(7):550-4.

48. Abiose BO, Ogunniyi J, Oyejide O. Oral soft tissue malignancies in Ibadan, Nigeria. Afr J Med Med Sci. 1991 Jun;20(2):107-13.
49. Adewole RA. Alcohol, smoking and oral cancer. A 10-year retrospective study at base hospital, Yaba. West Afr J Med. 2002 AprJun;21(2):142-5.

50. Adeyemi BF, Kolude BM, Akang EE. A retrospective histopathological review of oral squamous cell carcinoma in a nigerian teaching hospital. Afr J Med Med Sci. 2011 Jun;40(2):153-8.

51. Ajayi OF, Adeyemo WL, Ladeinde AL, Ogunlewe MO, Effiom OA, Omitola OG, et al. Primary malignant neoplasms of orofacial origin: A retrospective review of 256 cases in a Nigerian tertiary hospital. Int J Oral Maxillofac Surg. 2007 May;36(5):403-8

52. Amusa YB, Olabanji JK, Akinpelu VO, Olateju SO, Agbakwuru EA, Ndukwe N, et al. Pattern of head and neck malignant tumours in a Nigerian teaching hospital--a ten year review. West Afr J Med. 2004 Oct-Dec;23(4):280-5.

53. Arotiba JT, Obiechina AE, Fasola OA, Fawole OI, Ajagbe HA. Oral squamous cell carcinoma: A review of 246 Nigerian cases. Afr J Med Med Sci. 1999 Sep-Dec;28(3-4):141-4.

54. Arotiba GT, Ladeinde AL, Oyeneyin JO, Nwawolo CC, Banjo AA, Ajayi OF. Malignant orofacial neoplasms in Lagos, Nigeria. East Afr Med J. 2006 Mar;83(3):62-8.

55. Effiom OA, Adeyemo WL, Omitola OG, Ajayi OF, Emmanuel MM, Gbotolorun OM. Oral squamous cell carcinoma: A clinicopathologic review of 233 cases in Lagos, Nigeria. J Oral Maxillofac Surg. 2008 Aug;66(8):1595-9

56. Lawal A, Kolude B, Adeyemi BF, Lawoyin J, Akang E. Social profile and habits of oral cancer patients in Ibadan. Afr J Med Med Sci. 2011 Sep;40(3):247-51.

57. Lawoyin JO, Lawoyin DO, Aderinokun G. Intra-oral squamous cell carcinoma in Ibadan: A review of 90 cases. Afr J Med Med Sci. 1997 Sep-Dec;26(3-4):187-8.

58. Oji C, Chukwuneke FN. Oral cancer in Enugu, Nigeria, 1998-2003. Br J Oral Maxillofac Surg. 2007 Jun;45(4):298-301.

59. Otoh EC, Johnson NW, Olasoji HO, Danfillo IS, Adeleke OA. Intraoral carcinomas in Maiduguri, north-eastern Nigeria. Oral Dis. 2005 Nov;11(6):379-85.

60. Rafindadi AH, Ayuba GI. Oral tumours in Zaria. Niger J Surg Res. 2000 November;2:21.

61. Oburra HO. Late presentation of laryngeal and nasopharyngeal cancer in Kenyatta national hospital. East Afr Med J. 1998 Apr;75(4):223-6.

62. Afolabi O, Alabi B, Badmos K, Buhari M, Segun-Basari S. Clinicopathological pattern of nasopharyngeal carcinoma in Ilorin, Nigeria. Niger J Clin Pract. 2010 Oct-Dec;13(4):445.

63. Arotiba GT. Malignant neoplasms of the maxillary antrum in Nigerians. West Afr J Med. 1998 Jul-Sep;17(3):173-8.

64. Fasunla AJ, Lasisi AO. Sinonasal malignancies: A 10-year review in a tertiary health institution. J Natl Med Assoc. 2007 Dec;99(12):140710 .

65. da Lilly-Tariah OB. Cancer of the nose and paranasal sinuses in Jos: A 10 year study. West African J ORL-HNS. 1999;2(1):11.

66. da Lilly-Tariah OB, Somefun AO. Malignant tumours of the nasopharynx at Jos university teaching hospital, Nigeria. Niger Postgrad Med J. 2003 Jun;10(2):99-102.

67. Tumushime-Buturo CG, Bandason C, Makura ZG, Yousef OE. Cancer of the larynx at Harare central hospital in Zimbabwe. Cent Afr J Med. 1993 Aug;39(8):167-70.

68. Oyono SM, Njock R, Fouda A, Moune A, Bengono G. Prise en charge des cancers du larynx :Expérience d'un service ORL en afrique noire. Cahiers Sante. 2006 Apr-Jun;16(2):109-112.

69. Amusa YB, Badmus TA, Olabanji JK, Oyebamiji EO. Laryngeal carcinoma: Our experience at Obafemi Awolowo University Teaching 
Hospital Complex, Ile-Ife, Nigeria. Cent Afr J Med. 2009 SepDec;55(9-12):54-8.

70. Iseh KR, Abdullahi M, Aliyu D. Laryngeal tumours: Clinical pattern in Sokoto, northwestern Nigeria. Niger J Med. 2011 JanMar;20(1):75-82.

71. Nwaorgu OG, Ogunbiyi JO. Nasopharyngeal cancer at the university college hospital Ibadan cancer registry: An update. West Afr J Med. 2004 Apr-Jun;23(2):135-8.

72. Somefun OA, Nwawolo CC, Okeowo PA, Alabi SB, Abdul-Kareem FB, Banjo AA, et al. Prognostic factors in the management outcome of carcinoma of the larynx in Lagos. Niger Postgrad Med J. 2003 Jun;10(2):103-6.

73. Kpemissi E, Le Bourgeois M, Kpodzro K. Our experience of carcinoma of the larynx in Togo. Rev Laryngol Otol Rhinol (Bord). 1999;120(1):19-21.

74. Ndiaye I, Ndamage TD, Tall A, Diouf R, Diop EM. Profile of cancers of the hypopharynx in Senegal. Ann Otolaryngol Chir Cervicofac. 1997;114(3):86-9

75. Ndiaye IC, Diom ES, Diop F, Tall A, Ndiaye M, Essalki I, et al Squamous carcinoma of the hypopharynx in children in Senegal: Between disarray and enigma. Int J Pediatr Otorhinolaryngol. 2009 Mar;73(3):357-61.

76. Ndagi, F. D. Babalola, I. U. Mokwunye, et al., "Potentials and Challenges of Kolanut Production in Niger State, Nigeria," ISRN Agronomy, vol. 2012, Article ID 492394, 9 pages, 2012. doi: $10.5402 / 2012 / 492394$

77. Pullum TW. An assessment of age and date reporting in the DHS surveys, 1985-2003. DHS Methodological Reports. Calverton, MD: United States Agency for International Development; 2006. Report No.: 5 .

78. Howlader N, Noone AM, Krapcho M, Neyman N, Aminou R, Altekruse SF, Kosary CL, Ruhl J, Tatalovich Z, Cho H, Mariotto A, Eisner MP, Lewis DR, Chen HS, Feuer EJ, Cronin KA (eds).SEER Cancer Statistics Review, 1975-2009 (Vintage 2009 Populations), National Cancer Institute. Bethesda, MD, http://seer.cancer.gov/ csr/1975 2009 pops09/, based on November 2011 SEER data submission, posted to the SEER web site, 2012.SEER

79. Nasopharyngeal cancer [Internet]. Atlanta: American Cancer Society; 2012; cited March 6, 2013]. Available from:http://www.cancer. org/acs/groups/cid/documents/webcontent/003124-pdf.pdf.

80. McElrath K, Chitwood DD, Griffin DK, Comerford M. The consistency of self-reported HIV risk behavior among injection drug users. Am J Public Health. 1994 Dec;84(12):1965-70.

81. Chaturvedi AK, Engels EA, Pfeiffer RM, Hernandez BY, Xiao W, Kim E, Jiang B, Goodman MT, Sibug-Saber M, Cozen W, Liu L, Lynch CF, Wentzensen N, Jordan RC, Altekruse S, Anderson WF, Rosenberg PS, and Gillison ML Human Papillomavirus and Rising Oropharyngeal Cancer Incidence in the United States J Clin Oncol 2011 29:4294-4301

82. Chaturvedi AK, Engels EA, Anderson WF, Gillison ML. Incidence trends for human papillomavirus-related and -unrelated oral squamous cell carcinomas in the United States. J Clin Oncol. 2008 Feb $1 ; 26(4): 612-9$

83 Ragin CC, Taioli E. Survival of squamous cell carcinoma of the head and neck in relation to human papillomavirus infection: review and meta-analysis. Int J Cancer. 2007 Oct 15;121(8):1813-20.

84. Gillison ML, D'Souza G, Westra W, Sugar E, Xiao W, Begum S, Viscidi R. Distinct risk factor profiles for human papillomavirus type 16-positive and human papillomavirus type 16-negative head and neck cancers. J Natl Cancer Inst. 2008 Mar 19;100(6):407-20.

85. Quon H, Forastiere AA. Controversies in treatment deintensification of human papillomavirus-associated oropharyngeal carcinomas:
Should we, how should we, and for whom? J Clin Oncol. 2013 Feb 10;31(5):520-2.

86. Ondzotto G, Nkoua-Mbon JB, Fouemina T, Galiba J. Laryngeal cancer in women. report of 3 cases in Congo. Med Trop (Mars). 2002;62(6):671-2

87. El-Mofty SK, Zhang MQ, Davila RM. Histologic identification of human papillomavirus (HPV)-related squamous cell carcinoma in cervical lymph nodes: A reliable predictor of the site of an occult head and neck primary carcinoma. Head Neck Pathol. 2008 Sep;2(3):163-8.

88. HPV and cervical cancer: Unique challenges and opportunities for disease prevention [Internet]. Seattle: PATH; 2005 [updated July; cited February 7, 2013]. Available from: http://screening.iarc.fr/doc/ RH_HPV_unique_challenges.pdf.

89. HPV vaccine adoption in developing countries: Cost and financing issues [Internet]. Seattle: PATH; 2007 [updated December; cited February 7, 2013]. Available from: http://www.path.org/publications/ detail.php?i=1571.

90. Patel P, Hanson DL, Sullivan PS, Novak RM, Moorman AC, Tong $\mathrm{TC}$, et al. Incidence of types of cancer among HIV-infected persons compared with the general population in the United States, 1992-2003. Ann Intern Med. 2008 May 20;148(10):728-36.

91. Gillison ML. Oropharyngeal cancer: A potential consequence of concomitant HPV and HIV infection. Curr Opin Oncol. 2009 Sep;21(5):439-44.

92. Fagan JJ, Jacobs M. Survey of ENT services in Africa: Need for a comprehensive intervention. Glob Health Action. 2009 Mar 19;2:10.3402/gha.v2i0.1932.

93. The surgical workforce in the united states: Profile and recent trends [Internet].: American College of Surgeons Health Policy Research Institute; 2010; cited February 2, 2013]. Available from: http://www. acshpri.org/documents/ACSHPRI_Surgical_Workforce_in_US apr2010.pdf.

94. Population estimates: Vintage 2008 national tables [Internet]. Washington D.C.: United States Census Bureau; 2011; cited February 2, 2013]. Available from: http://www.census.gov/popest/data/ historical/2000s/vintage_2008/index.html.

95. Adeyi OA. Pathology services in developing countries-the West African experience. Arch Pathol Lab Med. 2011 Feb;135(2):183-6.

96. Rambau PF. Pathology practice in a resource-poor setting: Mwanza, Tanzania. Arch Pathol Lab Med. 2011 Feb;135(2):191-3.

97. Benediktsson H, Whitelaw J, Roy I. Pathology services in developing countries: A challenge. Arch Pathol Lab Med. 2007 Nov;131(11):16369.

98. Center for Workforce Studies. 2008 physician specialty data. Washington, DC: Association of American Medical Colleges; 2008.

99. Axios International. Cancer treatment and care in developing countries. Issues Paper. Paris: Axios International; 2009.

100. Central Statistical Agency [Ethiopia] and ICF International. Ethiopia demographic and health survey 2011. Addis Ababa, Ethiopia and Calverton, Maryland, U.S.A.: Central Statistical Agency and ICF International; 2012.

101. Kirkwood KM, Kosty MP, Bajorin DF, Bruinooge SS, Goldstein MA. Tracking the workforce: The american society of clinical oncology workforce information system. J Onc Prac. 2013;9(1):3-8.

102. Barton MB, Frommer M, Shafiq J. Role of radiotherapy in cancer control in low-income and middle-income countries. Lancet Oncol. $2006 \mathrm{Jul} ; 7(7): 584-95$.

103. DIRAC (DIrectory of RAdiotherapy centers) [Internet]. Vienna: International Atomic Energy Agency; 2012; cited February 2, 2012]. Available from:http://www-naweb.iaea.org/nahu/dirac/default.asp. 